\title{
Lexicography and the Relevance Criterion
}

\author{
Theo J.D. Bothma, Department of Information Science, \\ University of Pretoria, Pretoria, South Africa (tbothma@up.ac.za) and \\ visiting professor, Centre for Lexicography, Aarhus, Denmark \\ and \\ Sven Tarp, Centre for Lexicography, Business and Social Science, University \\ of Aarhus, Aarhus, Denmark (st@asb.dk) and visiting professor, Department of \\ Information Science, University of Pretoria, Pretoria, South Africa
}

\begin{abstract}
Until recently, lexicography and information science could rightly be considered two disciplines which had developed along parallel lines but with no or very little formal relation between them. Although the two disciplines developed in almost complete isolation from each other, during the last few years it has nevertheless become increasingly clear that they have a lot in common. This trend began within lexicography which started viewing lexicographical works as a special kind of tool designed to be consulted in order to obtain information. Upon this basis, it has been suggested that lexicography should be considered a part of information science and, hence, integrated into it (cf. e.g. Bergenholtz and Bothma 2012, Tarp 2009). It is evident that this integration of two hitherto independent disciplines with long traditions of their own is not something to be solved overnight and neither can it be a unilateral process.

This article will explore the concept of relevance in both disciplines in more detail and show, at the hand of examples from lexicographical tools, how the theoretical frameworks of both disciplines can complement one another. This will be done within the framework of the function theory of lexicography, as discussed in the many works of Tarp and Bergenholtz (e.g. Bergenholtz and Tarp 2002) and others, and relevance theory in information science as defined by Saracevic (1975, 1996), Cosijn and Ingwersen (2000) and others.
\end{abstract}

Keywords: LEXICOGRAPHY, FUNCTION THEORY, COGNITIVE SITUATIONS, COMMUNICATIVE SITUATIONS, OPERATIVE SITUATIONS, INTERPRETIVE SITUATIONS, PRE-LEXICOGRAPHICAL PHASE, INTRA-LEXICOGRAPHICAL PHASE, POST-LEXICOGRAPHICAL PHASE, INFORMATION SCIENCE, RELEVANCE THEORY, TOPICAL RELEVANCE, COGNITIVE RELEVANCE, SITUATIONAL RELEVANCE, SOCIO-COGNITIVE RELEVANCE, AFFECTIVE RELEVANCE

Opsomming: Leksikografie en die relevansie-kriterium. Tot onlangs kon leksikografie en inligtingkunde tereg gesien word as twee dissiplines wat langs parallelle lyne ontwikkel het, maar met min of geen formele verhouding tussen hulle nie. Alhoewel die twee dissiplines in bykans volkome isolasie van mekaar ontwikkel het, het dit gedurende die afgelope aantal jare al hoe meer duidelik geword dat hulle baie in gemeen het. Hierdie tendens het begin met leksikografie wat begin het om leksikografiese werke te sien as 'n spesiale tipe hulpmiddel ("tool") wat ontwerp is om geraadpleeg te word met die doel om inligting te bekom. Op grond hiervan is daar 
voorgestel dat leksikografie as deel van inligtingkunde gesien behoort te word, en gevolglik daarin geïntegreer behoort te word (sien bv. Bergenholtz en Bothma 2012, Tarp 2009). Dit is duidelik dat die integrasie van die twee tot-dusver onafhanklike dissiplines met lang tradisies van hulle eie nie iets is wat oornag opgelos sal kan word nie en dat dit nie 'n eensydige proses kan wees nie.

In hierdie artikel word die konsep van relevansie in beide dissiplines bespreek en word daar aan die hand van voorbeelde van leksikografiese hulpmiddels aangetoon hoe die teoretiese raamwerke van die twee dissiplines mekaar kan komplementeer. Dit sal gedoen word binne die raamwerk van die funksieteorie in leksikografie, soos bespreek in die talle werke van Tarp en Bergenholtz (bv. Bergenholtz en Tarp 2002) en andere, en relevansie-teorie in inligtingkunde soos gedefinieer deur Saracevic $(1975,1996)$, Cosijn en Ingwersen (2000) en andere.

Sleutelwoorde: LEKSIKOGRAFIE, FUNKSIETEORIE, KOGNITIEWE SITUASIES, KOMMUNIKATIEWE SITUASIES, OPERATIEWE SITUASIES, INTERPRETATIEWE SITUASIES, PRELEKSIKOGRAFIESE FASE, INTRA-LEKSIKOGRAFIESE FASE, POST-LEKSIKOGRAFIESE SITUASIE, INLIGTINGKUNDE, RELEVANSIETEORIE, TOPIKALE RELEVANSIE, KOGNITIEWE RELEVANSIE, SITUASIONELE RELEVANSIE, SOSIO-KOGNITIEWE RELEVANSIE, AFFEKTIEWE RELEVANSIE

\section{Introduction}

Until recently, lexicography and information science could rightly be considered two disciplines which had developed along parallel lines but with no or very little formal relation between them. Information science came into the world as an independent discipline in the first half of the 20th century and has experienced an enormous upsurge during the last decades due to, among other things, the rapid development of the corresponding technologies. Lexicography, on the other hand, is a thousand year-old cultural practice which has inevitably resulted in a large accompanying literature of academic reflections but with no systematic theory building until the 20th century, i.e. more or less the same period as information science was founded and flourished. Although the two disciplines developed in almost complete isolation from each other, during the last few years it has nevertheless become increasingly clear that they have a lot in common. The process was started by the trend within lexicography which in the final analysis viewed lexicographical works as a special kind of tool designed to be consulted in order to achieve information. Upon this basis, it has been suggested that lexicography should be considered a part of information science and, hence, integrated into it (cf. Tarp 2009, Leroyer 2011). While analyzing the problems related to innovation in e-lexicography, Bergenholtz and Bothma (2011: 74) conclude:

One of the reasons for the lack of innovation in e-lexicography is that lexicography is usually treated as a part of linguistics and lexicographical tools are primarily compiled by specialists with linguistic background. Our main thesis, namely that lexicography is not a part of linguistics but a part of information science does not support this line of thought. 
It is evident that this integration of two hitherto independent disciplines with long traditions of their own is not something to be solved overnight and neither can it be a unilateral process. Tarp (2011: 56) formulates the challenge in the following way:

In reality, what we are dealing with is one big discipline embracing all types of consultation tools designed to meet punctual information needs, a discipline which may be considered an integrated part of information science (...) In this respect, lexicography, on the one hand, has a lot to contribute to other theories dealing with punctual consultation tools and to information science in general, and on the other hand, has a lot to learn from these theories and this science.

Gouws (2011) supports this vision and stresses that learning from each other also means "unlearning", i.e. the capacity to recapitulate and view old stuff in a new light. The road ahead is still long and full of obstacles as there are still a lot of questions of common interest that have to be analyzed and solved. In this respect, Bothma (2011) as well as Bergenholtz and Bothma (2011) have dealt with the needs-adapted data presentation in e-information tools and have shown how information science may contribute to solve this complex problem which is shared by both disciplines. Similarly, in the following contribution we will discuss the criterion of relevance in a lexicographical light in order to see how this criterion - mainly but not exclusively developed in the field of information science - may be applied to lexicography and which consequences this application may have for the concept of relevance itself.

As we shall see, within lexicography the relevance criterion is already widely used, most frequently when the lexicographical process is analyzed in its various phases and important lexicographical decisions have to be taken in relation to specific dictionary projects and data categories. However, until now no attempt (that we are aware of) has been made to systematize and classify the different types and dimensions of relevance used. This may be considered a theoretical shortcoming with practical implications, especially in the present moment where lexicographical products are gradually being placed on electronic platforms requiring much more scientific stringency in all aspects in order to be high quality.

An obvious problem in the mutual approximation of two disciplines developed in isolation from each other - although sharing an overlapping subject field - is that they almost inevitably express themselves in different terminologies using different terms to express concepts that are more or less identical. For instance, when some lexicographic schools (Wiegand 2000, 2002, Tarp 2008a, 2009) employ the term data to denote what is selected and presented by lexicographers in dictionaries, information scientists would call it information although both parts would agree that what is finally retrieved from these data or information by the users of dictionaries is information. Such differences should not be an obstacle to a still closer collaboration between scholars from the two fields. Hence, in this contribution we have opted for the lexico- 
graphic terminology whereas in the next contribution it may be the other way around.

\section{The function theory: basic elements and relevance}

According to the latest research, lexicography has been a social and cultural practice for about four thousand years and has resulted in, at least, hundreds of thousands of dictionaries, encyclopedias, thesauruses and other types of lexicographical works covering almost all spheres of human activity and knowledge and using various sorts of media, from clay over papyrus and paper to modern electronic platforms. Within this immense discipline various general and specific theories of different scopes have been elaborated, especially during the last decades (cf. Tarp 2010). One of the very few general theories is the theory of lexicographical functions, henceforth referred to as the function theory. This theory is built upon the presumption that dictionaries and other lexicographical work are above all utility tools conceived and produced with the genuine purpose of satisfying specific types of human needs, i.e. information needs, existing in one or several individuals in society (cf. Bergenholtz and Tarp 2002, 2003, 2004, 2005, Tarp 2008a and b).

In order to determine the nature of the information needs relevant to lexicography, it is first of all necessary to establish a distinction between global information needs, i.e. the needs related to a more profound study of a specific subject field (or part of it), and punctual information needs, i.e. restricted and limited needs related to a single or limited topic within a larger subject field, or to the solution of specific tasks or problems. In this respect, dictionaries and other lexicographical works are par excellence consultation tools, i.e. artifacts designed to be consulted in order to meet punctual information needs in contrast to global information needs which may be satisfied by other types of artifacts or texts produced with a view to being read and studied from one end to another (cf. Tarp 2011).

However, it is important that the relation between the concepts of global and punctual needs should not be viewed as an absolute opposition but rather in a linear perspective as a relation between the whole and the part. In this respect, the lexicographical tradition shows several comprehensive works which treat what is considered global in other lexicographical works, as "punctual" and a part of a bigger whole. The big French Encyclopédie, ou Dictionnaire raisonné des sciences, des arts et des métiers is one such example. Here the user may find many relatively long articles, e.g. d'Alembert's (1754) article on dictionaries, which provide a "global" introduction to a specific field of knowledge but still considered within the global world knowledge (encyclopedia) and made accessible through a lexicographical structure. Another example is the Chinese Yongle Dadian from 1408 which was produced in order to collect and provide access to all knowledge existing in China at that moment and which among its 11,095 volumes included several already existing books on various topics which were 
incorporated, i.e. rewritten, in their totality into this gigantic lexicographical work and made accessible through a rhyming system for the characters as well as a complex system of indexes.

According to the function theory, the types of information needs relevant to lexicography should never be considered abstract needs, but specific and even concrete needs which are determined by the types of potential users of lexicography's practical works as well as the types of extra-lexicographical situations where lexicographically relevant information needs may occur, i.e. needs that may be satisfied by lexicographical tools. Of these two determining factors, the most important is the extra-lexicographical situation which also determines how many of the various lexicographically relevant characteristics of a potential type of user are relevant in each case. This also means that user needs should always be understood in their intimate relation to a specific type of situation and that they can never be defined only based upon the characteristics of a potential user however relevant these characteristics may be. At this stage, the function theory works with four fundamental types of lexicographically relevant situations (cf. Tarp 2008a):

1. Communicative situations where a need to solve a communication problem may occur.

2. Cognitive situations where a need for knowledge may occur.

3. Operative situations where a need for instructions on how to perform a physical or mental action may occur.

4. Interpretive situations where a need to interpret and understand a sign, signal, symbol etc. may occur.

The communicative situations are those that so far have been most studied, and they may be further subdivided into a number of situations such as text production and text reception in the mother tongue (or first language), text production and text reception in a foreign (or not-first) language, translation from mother tongue into a foreign language and vice versa, text revision etc. The needs that may occur, even for the same type of user, in these situations vary a lot: in text reception it may be the need to understand a word, in text production it may be a need for information about a word's syntactic properties, in translation it may be a need for an equivalent etc.

The cognitive situations may also be divided into various sub-situations, e.g. when someone needs to know something in order to perform a task (a journalist writing about Napoleon needs to know his day of birth and then most probably forgets it), when someone for whatever reason wants to know something specific and add it to his or her general or specialized knowledge, and when someone needs to know something specific related to a global study of a specific area of knowledge. The information needed in the two first cases 
may probably be of the same type for the same type of user, although for different purposes, whereas the information needed in the third case may also include references that relate the small topic to the bigger area of knowledge to which it belongs.

The operative and interpretive situations have so far been scarcely studied by lexicography and there are only relatively few lexicographical works that cater for these situations. They are, however, extremely interesting because they are situations which lexicography has in common with other references works e.g. user guides, how-to's and manuals - where users seek information in form of instructions in order to perform certain tasks or in form of explications of signs, signals, symbols, sounds, lights etc. in order to interpret them and determine whether something important and relevant is taking place and whether it is necessary to take action upon this basis.

The function theory claims that in order to produce high-quality lexicographical works and tools it is necessary to study the extra-lexicographical situations where information needs occur because these needs may vary considerably from one situation to another, even for the same type of user (cf. Tarp 2008b). This, of course, does not mean that the users and their characteristics are disregarded by the theory. A user with specific characteristics may have quite different information needs than another user with other characteristics, even when the needs are occurring in the same type of situation. A mothertongue speaker or an advanced learner of English will definitely have other needs than a learner at a beginner's level when writing an English text. An expert of biotechnology will need other types of information than a layman when consulting a specialized dictionary in order to get knowledge about a specific topic related to this discipline etc.

What the function theory claims at this point is that the relevant user characteristics depend on the situations where the relevant needs occur. First of all it should not be forgotten that any person may have an infinite number of characteristics of which most are lexicographically irrelevant, e.g. that a potential user is left-handed. Secondly, even the lexicographically relevant characteristics are not always relevant, i.e. relevant in each and every situation when information needs may occur. For instance, Danish users' different proficiency levels in English or knowledge of biotechnology are not relevant at all when they read a novel of Hans Christian Andersen and may need to have some oldfashioned words explained etc. but these levels will be highly relevant when they either want to be better informed about biotechnology or get assistance to produce an English text. To this end, the function theory has elaborated a list of lexicographically relevant user characteristics - an open list to which new characteristics can be added - from which the characteristics that are relevant to each type of extra-lexicographical situation can be selected. In this respect, the function theory works with a set of variables that have to be taken into account when determining the specific type of information needed in each case (cf. Tarp 2008b). 
According to the function theory, the user's information need is met by a corresponding set of lexicographical data which have been selected (manually or automatically from a corpus etc.), elaborated and prepared (by the lexicographer) and made accessible for consultation. The selection, elaboration and preparation of the data may be performed following various techniques and methods but in order to produce high-quality lexicographical works it is necessary that these techniques and methods in the final analysis are built upon the criteria of relevance determined by the specific type of information need in question.

When an individual person experiences an information need, he or she may then access the data and retrieve the needed information from these data through a complex cognitive process (which the theory does not study). Finally, the information retrieved may be used in various ways in order to satisfy the user's specific type of need, e.g. to solve a communicative or cognitive problem, to store it as knowledge, to perform a task or to interpret a sign, signal, symbol etc. This is, at least, what has happened in lexicography until a few years ago, where lexicographical works have only provided direct access to lexicographically selected, elaborated and prepared data, and not to data that have been prepared and made accessible elsewhere, e.g. in books and archives. Only recently, a few advanced lexicographical tools have tried to reuse already existing data made available through a data base or the Internet, and one of the visions today is not only to reuse these data but also to repackage and even recreate them adapting them to the specific information needs of the users in each situation (cf. Bothma 2011 and Tarp 2011).

As it has been indicated above, the function theory does not only study the processes taking place from the moment the user starts a consultation process to the moment where the needed information is retrieved from the lexicographical data, i.e. the intra-lexicographical consultation processes. It also studies the extra-lexicographical processes taking place immediately before and after the consultation process. The reason for this approach is double: on the one hand it is necessary to know in which situation the lexicographically relevant information needs occur in order to determine the nature of these needs, and on the other hand, it is absolutely necessary to evaluate the postlexicographical process in order to establish an objective criterion for success or failure instead of the subjective one used by questionnaires and the like. In this respect and according to the function theory, a "normal" lexicographical process is made up by the following phases:

1. a pre-lexicographical phase where a user with specific characteristics finding him or herself in a specific extra-lexicographic context or situation:

a. experiences an information need,

b. becomes aware of the information need,

c. and decides to start a lexicographical consultation; 
2. an intra-lexicographical phase where the user:

a. selects the relevant lexicographical information tool,

b. accesses the relevant data,

c. verifies that he or she has found the right data, i.e. relevant to the information need in question,

d. and retrieves the needed information from the data;

3. a post-lexicographical phase where the user:

a. makes use of the retrieved information in order to solve a communicative or cognitive problem, to store it as knowledge, to perform a task or to interpret a sign, signal, symbol etc.

Here it is important to emphasize that the above ideal process presupposes that the user is actually aware of the information need and decides to take lexicographical action. In fact, when a lexicographically relevant information need occurs for an individual in any pre-lexicographical situation, this individual is automatically transformed into a potential user which may:

1. not be aware of the information need and therefore not proceed to any lexicographical consultation;

2. be aware of the information need but not proceed to any lexicographical consultation because he or she thinks - maybe based upon previous lexicographical experience - that the need cannot be solved by means of a lexicographical consultation or that this consultation may require too much time and trouble;

3. be aware of the information need and proceed to a lexicographical consultation but based upon a wrong idea and understanding of the real nature of the information need; or

4. be aware of the real nature of the information need and proceed to a lexicographical consultation.

In an ideal world, lexicographical tools should be able to meet the user's information needs in all four cases, not only for the actual user in case 4 . In case 3, for instance, a lexicographical tool could by means of various advanced interactive techniques and methods guide the user in such a way that he or she finally will get the really needed information and not "the right answer to the wrong question". But even in cases 1 and 2 where the potential users for one reason or another do not by themselves start a consultation, there are already lexicographical tools available with solutions for the information needs occurring in specific types of situation in a digital environment. In this case, the above model will have to be transformed as follows:

1. a pre-lexicographical phase where the information need occurs but where the potential user for one reason or another does not take lexico- 
graphical action;

2. an intra-lexicographical phase where the lexicographical tool:

a. detects the problem,

b. and suggests a solution,

3. a post-lexicographical process where the user accepts the proposed solution and uses it in order to solve the hitherto unknown problem.

As mentioned, such advanced lexicographical tools already exist, e.g. Word's Spelling and Grammar Program which, when activated, detects problems and suggest solutions in relation to written text production in a digital environment.

In such cases, the intra-lexicographical process only takes a few seconds or even less. This should be compared with the above process where the user himself has to take lexicographical action, something which frequently may take several minutes. If, for instance, a professional translator needs to make 50 lexicographical consultations in a normal workday and these take an average of 5 minutes, this means 250 minutes, or more than four hours, of consultation, which for most people make up more than half a workday. This constitutes some rather expensive production costs (Nielsen 2008 calls them "lexicographical information costs") and, as such, a terrible waste of time. In this respect, the time factor - translated into a quick and easy data access and information retrieval - becomes another important criterion of lexicographical quality and relevance.

To sum up, this section has provided a brief presentation of the basic elements of the function theory and an introduction to the most important contexts where this theory refers to a relevance criterion. Relevance is first and foremost used to determine the types of information needs that are relevant to lexicography, i.e. those which can be satisfied by lexicographical works. It is then used to determine the extra-lexicographical situations and user characteristics relevant to lexicography in general and to a concrete lexicographical work in particular. It is also used to determine the data categories as well as the specific data needed to satisfy a specific type of information need. And finally, it is used with reference to the time factor, i.e. the duration of the intralexicographical process in terms of data access and information retrieval.

In all these cases, relevance is centered on the information needs and their satisfaction and combines extra- and intra-lexicographical elements. However, it must be admitted that nowhere in the lexicographical literature known to the authors of this contribution, is it possible to find a definition or a more extended discussion of the criterion of relevance in terms of lexicography. 


\section{Information science and the relevance criterion}

In information science research, Saracevic has, already in 1996, stated that "[n]obody has to explain to users of IR [Information Retrieval] systems what relevance is, even if they struggle (sometimes in vain) to find relevant stuff. People understand relevance intuitively" (Saracevic 1996; see also Saracevic 1975). However, Saracevic and others (e.g. Borlund 2000, Cosijn and Ingwersen 2000, Borlund 2003, Cosijn 2003, Cosijn and Bothma 2005, Ingwersen and Järvelin 2005) agree that there are many dimensions to relevance. Ingwersen and Järvelin 2005: 389, for example, defines relevance as

the perceived topicality, pertinence, usefulness or utility, etc., of information sources, made by cognitive actor(s) or algorithmic devices, with reference to an information situation [...] It can change dynamically over time for the same actor. Relevance can be of a low order objective nature or of higher order, i.e., of subjective multidimensional nature. Its measurement can be binary or graded.

Information sources could be information objects or humans as information sources (Ingwersen and Järvelin 2005: 386). An information object could be any physical or digital entity in a variety of media that could provide potential information and could refer to documents, texts, images and any other media (Ingwersen and Järvelin 2005: 385 and 386).

Two basic classes of relevance are distinguished, viz.

- objective relevance which is system-based (algorithmic or system relevance), and

- $\quad$ subjective relevance which is user-based and which can then be further subdivided.

Algorithmic or system relevance describes the relationship between a search query and the information objects. It "may be measured in terms of the comparative effectiveness of logical and/or statistical similarity of features inferring relevance"; it is system-oriented "because the success of the relation is entirely dependent on a given procedure or algorithm, and the intent behind it. Both the query and the objects contain identical/similar features, such as words and other strings of signs, image colour or author name" (Cosijn and Ingwersen 2000: 537, 539). A document is therefore relevant in terms of the search string when it contains identical or similar words as used in carrying out the search. Information retrieval systems may be exact match systems (typically Boolean systems) or best match systems. "Traditional Boolean systems facilitate binary relevance judgements, whereas best match systems, or a combination of best match and Boolean systems, are able to rank retrieved information by relevance" (Cosijn and Bothma 2005: 50). It is important to note that relevance ranking in all such systems is still systems-based, i.e. on the basis of algorithms 
and statistical analysis the system decides which documents are more relevant than others and should be ranked higher.

All other cases of relevance judgments are user-based, i.e. a user evaluates whether a document is relevant in terms of the information need, and not the retrieval system.

User-based relevance categories as defined in Borlund 2000, Cosijn and Ingwersen 2000, Borlund 2003, Cosijn 2003, Cosijn and Bothma 2005 and Ingwersen and Järvelin 2005 are:

- topical relevance,

- cognitive relevance or pertinence,

- situational relevance and

- socio-cognitive relevance;

- affective relevance.

Each of these types of relevance will be discussed below.

Topical relevance or topicality is defined as "the relation between the topic of the query and the topic of the assessed information objects" (Cosijn and Bothma 2005: 50). Topicality deals with the "aboutness relationship between document contents retrieved and request, as assessed by a person" (Ingwersen and Järvelin 2005: 237). ("Aboutness" refers to what a text or document, an image or any other information object is about and refers to the topic it discusses; it could be an inherent feature of the object as recorded in the metadata, or it could be dependent on the individual who interprets the information object.) Borlund calls this type of relevance "intellectual topicality", to "distinguish the subjective type of topical oriented relevance from algorithmic relevance" (Borlund 2003: 915). According to Ingwersen and Järvelin topical relevance signifies "the relationship between the aboutness of information objects and the aboutness of requests as perceived by an actor (whether task performer, searcher or judge in IR experiments). Owing to the human assessment (interpretation) this type of relevance is of subjective emotional and intellectual nature" (Ingwersen and Järvelin 2005: 391).

Cognitive relevance or pertinence is "measured in terms of the relation between the state of knowledge, or cognitive information need of the user, and the information objects as interpreted by that user. The criteria by which pertinence is inferred are cognitive correspondence, informativeness, novelty and information preferences" (Cosijn and Bothma 2005: 51). "Pertinence represents the intellectual relation between the intrinsic human information need and the information objects as currently interpreted or perceived by the cognitive state of an assessor or user" (Borlund 2003: 915). It is dependent on the novelty value of the information for the user, i.e., to what extent it adds new information in the specific user situation. (In standard English "pertinence" and "relevance" are 
synonyms, but in relevance theory in information science both words are regarded as technical terms with distinct meanings, with "relevance" the broader term and "pertinence" a narrower term.)

Situational relevance "describes the relationship between the perceived situation, work task or problem at hand and the usefulness of the information objects as perceived by the user. The criteria by which situational relevance is inferred are usefulness in decision-making, appropriateness of information in problem solving and the reduction of uncertainty" (Cosijn and Bothma 2005: 53). According to Borlund (2000) "the judgement of situational relevance embraces not only the user's evaluation of whether a given information object is capable of satisfying the information need, it offers also the potential of creating new knowledge which may motivate change in the decision maker's cognitive structures. The change may further lead to a modification of the perception of the situation and the succeeding relevance judgement, and in an update of the information need". Situational relevance is therefore understood "as the utility or usefulness of the viewed and assessed information object(s) by pointing to the relationship between such retrieved object(s) and the work task at hand underlying the information need as perceived by the user. Situational relevance is a highly context dependent as well as a potentially dynamic type of relevance" (Borlund 2003: 915).

Socio-cognitive relevance describes "the relationship between the situation, the work-task or problem at hand in a given socio-cultural context on the one hand, and the information objects on the other, as perceived by one or more cognitive agents. The social or organizational domain, or cultural context in which the individual finds himself is defined by a paradigm, which dictates what problem explanations may be found to be acceptable" (Cosijn and Bothma 2005: 53). Cosijn and Ingwersen (2000: 549) state that socio-cognitive relevance "is highly context dependent and associated with organizational strategies or scientific community interaction within".

A further type of relevance is listed by Saracevic (1996), viz. motivational or affective relevance. Many researchers, however, currently regard this as "forming a natural part of all the subjective relevance categories" (Ingwersen and Järvelin 2005: 237), as also explained by Cosijn and Bothma, who state that affective relevance can be described "in terms of the relation between the goals, intents and motivations of the user and the information objects. Affective relevance should not be seen as the ultimate subjective relevance in a scale of relevances, but rather as another dimension of relevance judgments that may be associated with the other subjective types of relevance" (Cosijn and Bothma 2005: 55), as well as Borlund, who agrees that "motivational/affective relevance is a characteristic of all of the subjective types of relevance" (Borlund 2003: 915).

The interrelationship between work task performance, search task performance and relevance is illustrated in Figure 1, taken from Cosijn and Bothma 2005: 48. 


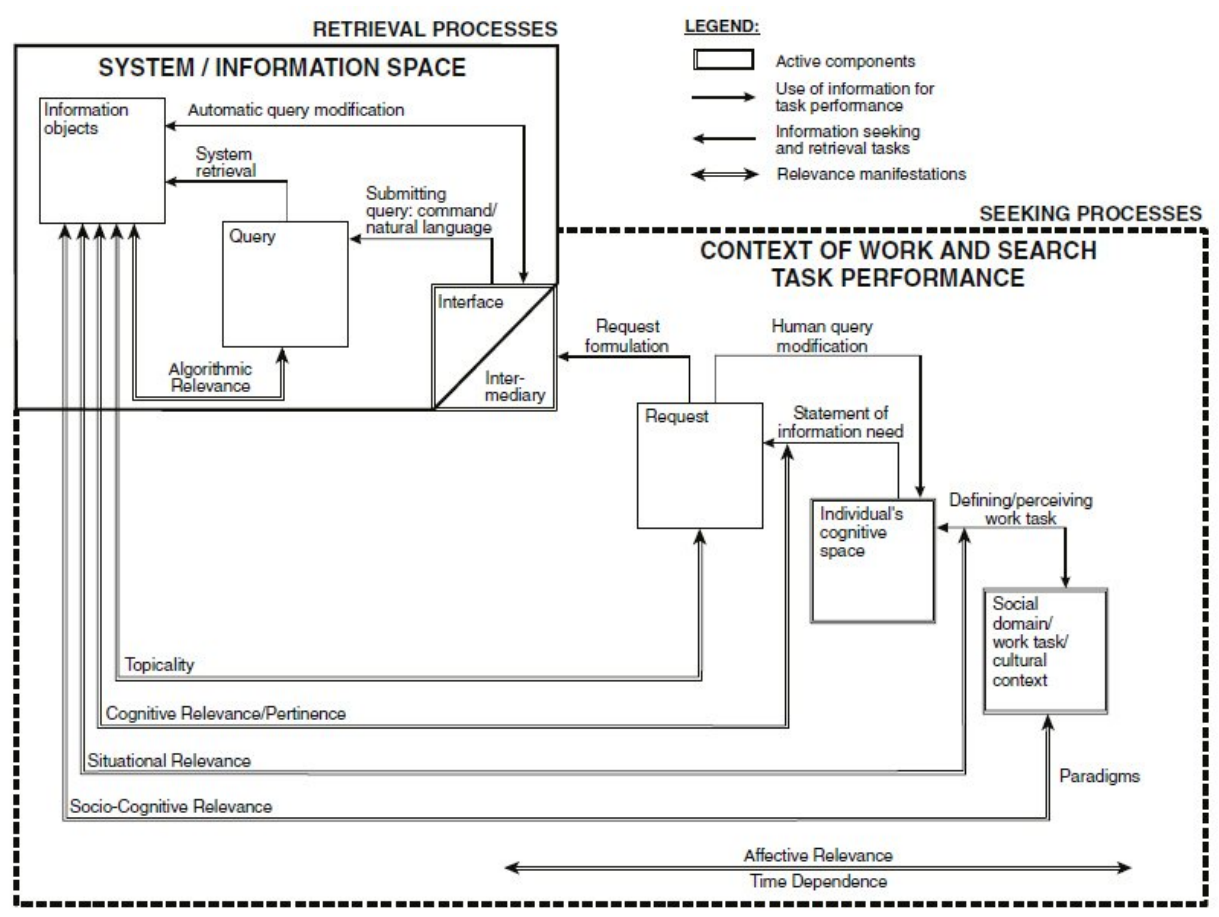

Figure 1: "Interactive Information Retrieval: Work task performance, search task performance and relevance types", as illustrated in Cosijn and Bothma 2005: 48

Relevance theory therefore studies the relationship between a human user (an actor) and an information object (e.g. a text document or other sources, as explained in section 3) in a given situation or context. Specific data may be relevant or not relevant for a specific user in a specific situation based on a combination of objective and subjective criteria. Objective relevance is based on a match between search terms and information objects (in the case of text-based information objects): if the search terms occur in the document, the document is deemed relevant. Whether the document is actually useful in terms of the information need is, however, a different matter. The document may not contain the required amount of detail, or too much detail; the data may be too complex (e.g. aimed at an expert when the user is a lay person) or not complex enough (e.g. a popular discussion of a topic when detailed, technical information is required). The data may be in a language with which the user is not sufficiently familiar. The data may not necessarily be relevant in a given situation or context because the problem that the data addresses or solves are not related to the specific work task the user is involved in at that stage. The data may be biased in terms of a specific theoretical or ideological framework with which 
the user may not be sufficiently familiar or with which he or she does not agree. There may therefore be a number of factors that influence a user's perception about how relevant the data are that has been identified by the system as relevant - even though the system may indicate that the data are (objectively) relevant, the user's information need may not necessarily be satisfied.

The question is to what extent these relevance criteria can be mapped to the function theory as discussed in section 2 , specifically referring to the three phases of the "normal" lexicographic process. This will be attempted in the following section by discussing a number of examples from various dictionaries.

\section{Illustrative example}

In this section we will discuss relevance in terms of the information needs which a non-native speaker of English may experience when engaged in written text production and the corresponding lexicographical data required to meet these information needs. However, initially it is necessary to underline that the potential user, i.e. the non-native speaker of English in question, may experience two fundamental types of need when transforming him or herself from a potential into an actual user of a learner's dictionary, i.e. the need directly related to written text production and the need related to the consultation process itself. According to Tarp (2008b: 152-153), a learner of a non-native language (L2) engaged in written text production may have the following information needs directly related to the production process:

- Information about L2 words:

- orthography

- word class

- genus (not relevant for English)

- pragmatic and cultural restrictions

- inflection

- word formation

- syntactic properties

- Information about L2 two collocations

- Information about L2 idioms

- Information about L2 proverbs

- Information about L2 derivates

- Information about L2 synonyms, antonyms, hyponyms etc.

As to the needs exclusively related to the consultation process, the actual user may need access via the native language (especially when he or she is not an advanced learner) as well as information that may verify that he or she has 
actually found the right lemma, idiom or proverb (cf. Tarp 2008b: 153):

- Information about L2 words:

- meaning

- orthography (in case of variant)

- word class

- genus (not relevant for English)

- Information about meaning of L2 idioms

_ Information about meaning of L2 proverbs

It goes without saying that these two lists may be extended and further specified and that they in any case should be adapted to the language in question (writing in African languages would for instance present other types of information needs), but the above mentioned information needs are without any doubt the most important in terms of problems related to written text production in English as a non-native language. They are attributes of relevance which may vary as a function of the actual user's proficiency level and as such they require specific lexicographical data in order to be satisfied. In this respect, it is important to stress that the above lists contain the hypothetical needs that may occur in a specific type of extra-lexicographical situation, i.e. written text production. In a concrete situation and subsequent concrete consultation, a dictionary user will only very rarely experience all these information needs, but as a rule only one or a few of them in any possible combination. This means, on the one hand, that any printed dictionary with static articles will have to include lexicographical data designed to meet all these needs if it really wants to be an information tool in terms of written text production in a non-native language, and, on the other hand, that electronic dictionaries should consider incorporating an access system that allows only the required data to pop up on the screen in a concrete and specific consultation, i.e. providing dynamic articles adapted to the specific and concrete information needs of the user in any extralexicographical situation (cf. Bergenholtz and Bothma 2011, Bothma 2011, Tarp 2011).

In the following we will look at the online Oxford English Dictionary as well as one of the "big five" English learners' dictionaries taken at random, the Cambridge Learner's Dictionary, and see how it meets the user's information needs in terms of written text production which is one of its declared functions.

On its web site, the first of these two dictionaries describes itself as follows:

The Oxford English Dictionary (OED) is widely regarded as the accepted authority on the English language. It is an unsurpassed guide to the meaning, history, and pronunciation of 600,000 words - past and present - from across the English-speaking world. As a historical dictionary, the OED is very different 
from those of current English, in which the focus is on present-day meanings. You'll still find these in the OED, but you'll also find the history of individual words, and of the language - traced through 3 million quotations, from classic literature and specialist periodicals to films scripts and cookery books (http://www.oed.com/public/about).

Already from this description it seems clear that the Oxford English Dictionary is not the most adequate dictionary to assist a foreign learner of English having text-production problems. If this user, for instance, needs some appropriate collocations with the word table and accesses the corresponding article then the dictionary will come up with an article containing almost 35,000 words covering about 90 pages in a MS Word document. Although the needed collocations may be found among all these words, this is a typical example of information overload which may take the user on a long odyssey until the information need is finally satisfied, if ever, unless the user had a cognitive information need and wanted to know as much as possible about the specific word. If one therefore searches for the word "table" in the OED, the above-mentioned article will be relevant at the system or algorithmic level, but not at any other level if the user does not have a cognitive information need. However, if the $O E D$ were to offer the option of searching for and displaying only specific types or subsets of data (e.g. only grammatical features of the word concerned) the retrieved data could be relevant at the topical and situational levels as well. For this to be possible, it would require that the data be structured in such a way that only specified subsets of data be displayed and that the search interface allow the user to specify exactly which subset(s) of data should be displayed (cf. Bothma 2011).

A quite different situation will meet the user if he or she decides to consult the Cambridge Learner's Dictionary which, according to its own Introduction, is "the perfect dictionary for the intermediate and upper-intermediate learner of English". Although the concept of intermediate learner is controversial and highly imprecise in terms of lexicography as shown by Tarp (2008b: 138-141), there is little doubt that this concept in one way or another refers to a learner with a limited English vocabulary for which reason access through the native language will frequently be required in relation to text production. In this very important aspect, the Cambridge Learner's Dictionary does not provide the necessary tool to assist the user and therefore cannot be considered the "perfect dictionary" for the user group in question. If we abstract from this "little" problem and proceed directly to the dictionary's lemma list, we will among tens of thousands other articles find the following one:

anticipate /æn'tisipeit/ verb [T] to expect something, or to prepare for something before it happens to anticipate a problem 0 [+ that] We anticipate that prices will fall next year.

This article seems to include the necessary data needed by the user to verify 
that he or she has arrived at the right article, i.e. meaning and word class of anticipate, as there is no orthographic variant and no proverb or idioms of relevance to explain. Apart from that, meaning is provided based upon a controlled and restricted vocabulary of 2,000 common English words making it much easier for the intermediate learner to understand. As to the information needs related directly to text production it provides information about orthography, pronunciation (not relevant for written production), word class and syntactic properties, but not about collocations, derivates (e.g. anticipation which can, however, be found in the subsequent article), and synonyms (expect is only provided implicitly in the short definition). Neither does it provide information about inflection, but as anticipate is a regular verb it may be expected that the envisaged group of intermediate learners will know how to inflect it. Although it exemplifies the explicit syntactic data ( $T$ for transitive and that-clause) with small sentences that may help the intended user group to understand these codified data, the main problem is nevertheless the relatively scarce information in this respect compared with some of the other "big five" learners' dictionaries. Longman Dictionary of Contemporary English, for example, provides also "it is anticipated that" and "anticipate doing sth", while the Macmillan English Dictionary for Advanced Learners adds "anticipate (sb/sth) doing sth", i.e. frequent syntactic constructions that the intermediate learners may need when performing written text production in English.

To sum up, an intermediate learner of English (the foreseen user type), when having problems with the specific word anticipate in a specific type of extra-lexicographical situation, namely written text production, that leads to a subsequent consultation of a printed dictionary, may need information about orthography, word class, syntactic properties, collocations, derivates and synonyms. The corresponding lexicographical data furnished in the dictionary provide solutions for all of these information-need categories, but only orthography, word class and syntactic properties are covered by the provision of explicit data whereas collocations, derivates and synonyms are covered implicitly or in another article (anticipation). To this should be added that the important syntactic data are only included partially (transitive and normal thatclause) whereas highly relevant syntactic data such as "it is anticipated that", "anticipate doing something" and "anticipate (somebody or something) doing something" are completely missing together with data that permit the user to access anticipate via his or her native language.

In all dictionary consultations mentioned above, the data would therefore again be relevant at the system or algorithmic level. However, if the user had a broader cognitive information need, his/her information need would in most cases not be satisfied. Since the article in the Cambridge Learner's Dictionary is very short, there would be no danger of information overload, but a lack of detail may cause a problem for the user. Therefore, even though the data may be relevant at the topical, cognitive and situational levels, the data offered to the user may be incomplete and may only fulfill the user's information need 
partially: the user may not be able to carry on with his/her work task and may have to consult other information sources. This stresses the important role of the compiler of an information tool to ensure that the data taken up in the database is sufficient to solve the specified information needs of the potential user in a specified type of situation: insufficient data are as big a problem as information overload.

\section{The lexicographical process and the various dimensions of relevance}

In the following examples the above discussion is related to the various phases in the lexicographical process outlined in section 2 (i.e. the process viewed with the eyes of the user) as well as to the dimensions of relevance presented in section 3. We can now say that the broader extra-lexicographical context or situation as well as the specific situation (written text production in a foreign language) in which the user with specific characteristics finds him- or herself are instances of socio-cognitive relevance in terms of information science. The situation when an information need occurs due to a communicative problem and the phases where the user becomes aware of this need and decides to take lexicographical action, are all examples of situational relevance.

When the user proceeds to the intra-lexicographical phase and, as a first step, selects the appropriate information tool, this selection could be a case of socio-cognitive relevance or situational relevance. The choice of a specific information tool would have a socio-cognitive dimension if the user decides on a specific tool based on his or her knowledge of multiple tools available, is aware of the content, approaches to data selection and presentation, possible biases etc. of each of the tools. However, the choice of tool would usually be based on situational relevance as well, if the user simply chooses tool A over tool B without indepth knowledge of the design and compilation criteria of the creators of the tool, but simply on the basis of the perceived usefulness of the two tools. As to the two information tools chosen and discussed in the previous section, the Oxford English Dictionary and the Cambridge Learner's Dictionary, both are examples of topical relevance because they relate to the topic of the information need, but due to the information overload of the former in terms of text production, only the latter is a case of situational relevance.

Whereas all other phases and sub-phases of the overall lexicographical process are instances of subjective, user-based relevance, the sub-phase where the user accesses the data is a clear case of objective, system-based relevance, either based upon algorithms in an online environment or the user's knowledge of the alphabet used as access route in the printed dictionary.

In the following intra-lexicographical sub-phase the user verifies that the article accessed (anticipate) is actually the right one and contains the data required, e.g. data about orthography, word class and syntactic properties. This verification is without any doubt a case of cognitive relevance whereas the subsequent retrieval of the needed information provides an example of situational 
relevance.

Affective relevance could, as indicated in section 3, occur across all dimensions of relevance. This applies to affective relevance in the lexicographical process as well. Examples would be where the user decides to ignore an information need based on extraneous factors (e.g. a lack of time or interest in solving the information), a decision not to consult a specific tool based on issues not related to the possibility of the tool providing a solution to the information need, a decision not to use e-information tools because of lack of knowledge about how effectively to access or use the tools, etc.

So far so good! The various pre- and intra-lexicographical phases and subphases described in section 2 seem to be perfectly covered by the various dimensions of relevance treated in information science. However, when it comes to the post-lexicographical phase where the user makes use of the retrieved information in order to solve problems, perform a task, etc., none of the described dimensions of relevance seems to cover the phase, although it must be considered a very import phase because it is here that it is proven in practice if the retrieved information is actually the information needed, cf. "the proof of the pudding is in the eating".

\section{Conclusion}

In this contribution we have tried to unify criteria from two disciplines which have so far developed in almost complete isolation from each other although they, without any doubt, share a common interest in providing access to data and information. It is not an easy task as both disciplines have their own deeprooted traditions and different starting points.

Specific sub-disciplines within information science (e.g. information organisation and retrieval) have until now mainly been dedicated to the study and development of systems, technologies and techniques that may provide access to already existing and relatively big documents (books, articles etc.) as well as illustrations and other types of data sources from where information can be retrieved. In this respect, information science works almost exclusively with cognitive needs as they are defined in the function theory.

Lexicography, on the other hand, also studies and develops systems and techniques that allow the users to access relevant data and retrieve the required information. However, when this is said, traditional lexicography differs from information science in at least three ways:

1. the information needs covered by lexicographical works are not only cognitive but also communicative, operative and interpretive;

2. the cognitive needs covered are in most cases (but not always) needs that may be met by relatively small sets of data;

3. the data to which access is provided are, as a rule, not already existing 
data but data selected, elaborated and prepared by the lexicographer.

In spite of these obvious differences, history provides various overlapping examples where lexicographical works have been planned and produced according to principles similar to those of information science. The Chinese Yongle Dadian (1408) described in section 2 is such an example as it provides access both to completely new data written by the authors and to already existing books. The New Palgrave Dictionary of Economics Online (2012) is another example of a lexicographical work which provides access to a huge number of scientific articles written by distinguished economists based upon principles that completely overlap those of information science.

It may therefore not surprise anyone that the discussion in the previous section has shown that the theory of relevance and all its dimensions are perfectly applicable to lexicography, especially when the various phases and subphases of the lexicographical process as it is conceived from the point of view of the user are analyzed in this perspective. The only really big surprise is that the relevance criteria do not seem to apply to the final post-lexicographical phase when the user of the lexicographical tool makes use of the information retrieved in order to solve a communicative or cognitive problem, to store it as knowledge, to perform a task or to interpret a sign, signal, symbol etc. The explanation may be that information organization and retrieval as a sub-discipline of information science, as mentioned, has hitherto mainly worked with large sets of data and information for cognitive purposes and that it is much more difficult to test in practice whether the information eventually stored in the brain is actually the relevant one, whereas this is relatively easy to do when the problem, for instance, is related to written text production. Other sub-disciplines of information science are, however, interested in the use of the data and information, e.g. information (and knowledge) management - the basic tenet is that information (and knowledge) is to be managed so that it can be interpreted for decision making and therefore assist in the work task execution. At this level it again links to lexicography - even though the dimensions of relevance are not used to describe this process.

Why is this comparison important at the theoretical level, for both information science and lexicography?

For information science the comparison is important because it is evident that, in information science, the theory of relevance stops at a crucial stage, viz. before the use of the information. It deals with retrieval issues and judgment of relevance of the retrieved information, but does not deal at all with the actual use of the information to solve problems or help in decision making. In addition, information science deals mainly or solely with cognitive information needs, and the different user situations as defined in the function theory are not distinguished. This research indicates that the theory of relevance in information science should be expanded to include the "post-lexicographical phase", i.e., the actual situation where the information is used, as well as a more finely 
grained situation assessment. This is an important theoretical consideration for information science and requires further research in information science.

In lexicography, relevance theory as outlined and illustrated above, provides an elegant theory to understand relevance as a complex phenomenon that may have a profound influence on lexicographers' analysis of users' information needs. Users' information needs are paramount for lexicographers to decide what data are to be shown to the user in any given usage situation, as is evident from function theory (and even general lexicographic practice). Relevance theory implies that lexicographers have to make an even more in-depth study of the users of their products to enable them to understand exactly what may influence a user to use or not use a specific dictionary and to ensure that the lexicographic offering presents to the user only the required data to solve the user's information need in a given situation - no more and no less. If lexicographers understand that there are multiple relevances that may influence a user's judgment they may be able to design the underlying databases and filtering mechanisms in such a way that the end product provides the ideal solution for every user in every usage situation. This requires additional research in both metalexicography and lexicographical practice, especially at the level of database design and the design of filtering mechanisms.

Research in relevance theory therefore enriches the theoretical underpinnings of both information science and lexicography, and has a practical implication for providing better information tools (lexicographic information tools as well as other information tools) to users of such tools.

\section{References}

\section{Lexicographical works}

Cambridge Learner's Dictionary. Woodford, Kate (Ed.). 2010. Cambridge Learner's Dictionary. Cambridge: Cambridge University Press

Encyclopédie, ou Dictionnaire raisonné des sciences, des arts et des métiers. Diderot, Denis and Jean le Rond d'Alembert (Eds.). 1751-72. Encyclopédie, ou Dictionnaire raisonné des sciences, des arts et des métiers. Volume 1-28. Paris: André le Breton, Michel-Antoine David, Laurent Durand and Antoine-Claude Briasson.

Longman Dictionary of Contemporary English. Summers, Della (Ed.). 2003. Longman Dictionary of Contemporary English. Harlow: Longman.

Macmillan English Dictionary for Advanced Learners. Rundell, Michael (Ed.). 2002. Macmillan English Dictionary for Advanced Learners. London: Macmillan Education.

Oxford English Dictionary. Simpson, John (Ed.). 2012. Oxford English Dictionary. Oxford: Oxford University Press. [Online] Available: http://www.oed.com.

The New Palgrave Dictionary of Economics Online. Durlauf, Steven N. and Lawrence E. Blume (Eds.). 2012. The New Palgrave Dictionary of Economics Online. Hampshire: Palgrave Macmillan. [Online] Available: http:/ /www.dictionaryofeconomics.com/dictionary.

Yongle Dadian. Xie, Jin (Ed.). 1408. Yongle Dadian. Volume 1-11 095. China. 


\section{Other literature}

d'Alembert, Jean le Rond. 1754. Dictionnaire. Diderot, Denis and Jean le Rond d'Alembert (Eds.). 1754. Encyclopédie, ou Dictionnaire raisonné des sciences, des arts et des métiers. Tome IV: 958-969. Paris: André le Breton, Michel-Antoine David, Laurent Durand and Antoine-Claude Briasson.

Bergenholtz, Henning and Theo J.D. Bothma. 2011. Needs-adapted Data Presentation in e-Information Tools. Lexikos 21: 53-77.

Bergenholtz, Henning and Sven Tarp. 2002. Die moderne lexikographische Funktionslehre. Diskussionsbeitrag zu neuen und alten Paradigmen, die Wörterbücher als Gebrauchsgegenstände verstehen. Lexicographica 18: 253-263.

Bergenholtz, Henning and Sven Tarp. 2003. Two Opposing Theories: On H.E. Wiegand's Recent Discovery of Lexicographic Functions. Hermes, Journal of Linguistics 31:171-196.

Bergenholtz, Henning and Sven Tarp. 2004. The Concept of "Dictionary Usage". Dollerup, Cai (Ed.). 2004. Worlds of Words. A Tribute to Arne Zettersten. Nordic Journal of English Studies 3(1): 23-36.

Bergenholtz, Henning and Sven Tarp. 2005. Wörterbuchfunktionen. Barz, Irmhild, Henning Bergenholtz and Jarmo Korhonen (Eds.). 2005. Schreiben, Verstehen, Übersetzen, Lernen. Zu einund zweisprachigen Wörterbüchern mit Deutsch: 11-25. Frankfurt am Main/Bern/New York/ Paris: Peter Lang.

Borlund, Pia. 2000. Evaluation of Interactive Information Retrieval Systems. Doctoral Thesis. Åbo: Åbo Akademi University Press.

Borlund, Pia. 2003. The Concept of Relevance in IR. Journal of the American Society for Information Science and Technology 54(10): 913-925.

Bothma, Theo J.D. 2011. Filtering and Adapting Data and Information in the Online Environment in Response to User Needs. Fuertes-Olivera, Pedro A. and Henning Bergenholtz (Eds.). 2011. e-Lexicography: The Internet, Digital Initiatives and Lexicography: 71-102. London/New York: Continuum.

Cosijn, Erica. 2003. Relevance Judgements in Information Retrieval. Unpublished D.Phil. Thesis. Pretoria: University of Pretoria.

Cosijn, Erica and Theo J.D. Bothma. 2005. Contexts of Relevance for Information Retrieval System Design. Crestani, Fabio and Ian Ruthven (Eds.). 2005. Context: Nature, Impact, and Role. 5th International Conference on Conceptions of Library and Information Sciences, CoLIS 2005, Glasgow, UK, June 4-8, 2005: 47-58. Berlin/Heidelberg: Springer.

Cosijn, Erica and Peter Ingwersen. 2000. Dimensions of Relevance. Information Processing and Management 36(4): 533-550.

Gouws, Rufus H. 2011. Learning, Unlearning and Innovation in the Planning of Electronic Dictionaries. Fuertes-Olivera, Pedro A. and Henning Bergenholtz (Eds.). 2011. e-Lexicography: The Internet, Digital Initiatives and Lexicography: 17-29. London/New York: Continuum.

Ingwersen, Peter and Kalervo Järvelin. 2005. The Turn: Integration of Information Seeking and Retrieval in Context. Dordrecht: Springer.

Leroyer, Patrick. 2011. Change of Paradigm: From Linguistics to Information Science and from Dictionaries to Lexicographic Information Tools. Fuertes-Olivera, Pedro A. and Henning Bergenholtz (Eds.). 2011. e-Lexicography: The Internet, Digital Initiatives and Lexicography: 121-140. London/New York: Continuum. 
Nielsen, Sandro. 2008. The Effect of Lexicographical Information Costs on Dictionary Making and Use. Lexikos 18: 170-189.

Saracevic, Tefko. 1975. Relevance: A Review of and a Framework for the Thinking on the Notion in Information Science. Journal of the American Society for Information Science and Technology 26(6): 321-343.

Saracevic, Tefko. 1996. Relevance Reconsidered '96. Ingwersen, P and N.O. Pors (Eds.). 1996. Proceedings of CoLIS 2, the Second International Conference on Conceptions of Library and Information Science: Integration in Perspective, 13-16 October 1996: 201-218. Copenhagen: The Royal School of Librarianship.

Tarp, Sven. 2008a: Revival of a Dusty Old Profession. Hermes, Journal of Linguistics 41: 175-188.

Tarp, Sven. 2008b. Lexicography in the Borderland between Knowledge and Non-knowledge. General Lexicographical Theory with Particular Focus on Learner's Lexicography. Lexicographica. Series Maior 134. Tübingen: Max Niemeyer.

Tarp, Sven. 2009. Beyond Lexicography: New Visions and Challenges in the Information Age. Bergenholtz, Henning, Sandro Nielsen and Sven Tarp (Eds.). 2009. Lexicography at a Crossroads: Dictionaries and Encyclopedias Today, Lexicographical Tools Tomorrow. Linguistic Insights. Studies in Language and Communication 90: 17-32. Bern: Peter Lang.

Tarp, Sven. 2011: Lexicographical and Other e-Tools for Consultation Purposes: Towards the Individualization of Needs Satisfaction. Fuertes-Olivera, Pedro A. and Henning Bergenholtz (Eds.). 2011. e-Lexicography: The Internet, Digital Initiatives and Lexicography: 54-70. London/ New York: Continuum.

Wiegand, Herbert Ernst. 2000. Wissen, Wissenrepräsentationen und Printwörterbücher. Heid, Ulrich, Stefan Evert, Egbert Lehmann and Christian Rohrer (Eds.). 2000. Proceedings of the Ninth EURALEX International Congress. EURALEX 2000, Stuttgart, Germany, August 8-12, 2000: 15-38. Stuttgart: Institut für Maschinelle Sprachverarbeitung, Universität Stuttgart.

Wiegand, Herbert Ernst. 2002. Wissen in der Sprachlexikografie. Ein Plädoyer für einige immer noch notwendige Differenzierungen. Ezawa, Kennosuke, Wilfried Kürschner, Karl H. Rensch and Manfred Ringmacher (Eds.). 2002. Linguistik jenseits des Strukturalismus. Akten des II. OstWest-Kolloquiums Berlin 1998: 265-281. Tübingen: Gunter Narr Verlag. 